Tropical Journal of Pharmaceutical Research April 2020; 19 (4): 797-803

ISSN: $1596-5996$ (print); 1596-9827 (electronic)

(C) Pharmacotherapy Group, Faculty of Pharmacy, University of Benin, Benin City, 300001 Nigeria.

Available online at http://www.tjpr.org

Original Research Article

http://dx.doi.org/10.4314/tjpr.v19i4.17

\title{
Benjakul supplementation improves hepatic fat metabolism in high-fat diet-induced obese rats
}

\author{
Achiraya Kamchansuppasin ${ }^{1 *}$, Kevalin Vongthoung ${ }^{2}$, Pornthep Temrangsee ${ }^{1}$, \\ Narongsuk Munkong ${ }^{3}$, Nusiri Lerdvuthisopon ${ }^{4}$ \\ ${ }^{1}$ Office of Graduate Studies, Faculty of Medicine, Thammasat University, Pathum Thani, ${ }^{2}$ Faculty of Medicine, Ramathibodi \\ Hospital, Mahidol University, Bangkok, ${ }^{3}$ Office Department of Medicine, School of Medicine, University of Phayao, Phayao, \\ ${ }^{4}$ Department of Preclinical Science, Faculty of Medicine, Thammasat University, Pathum Thani, Thailand
}

*For correspondence: Email: achiraya_chi@yahoo.com; Tel: +66 972671932

Sent for review: 4 August 2018

Revised accepted: 25 January 2020

\begin{abstract}
Purpose: To evaluate the effects of Benjakul water extract (BWE) supplementation for the prevention of hepatic fat metabolic dysfunction in a rat obesity model induced by a high-fat diet (HFD).

Methods: Forty male outbred Sprague-Dawley rats were separated into six groups according to diet composition and treatment: control, HFD, and HFD supplemented with Benjakul extraction at low and high dose (41.3 and $413 \mathrm{mg} / \mathrm{kg} / \mathrm{day}$, respectively). After 4 weeks, blood biochemical parameters (i.e., hepatic 3-hydroxy-3-methylglutaryl coenzyme A reductase (HMGCR) enzyme and liver histological features) were examined. Subsequently, hepatic gene expression of sterol regulatory element binding protein-1 (SREBP-1) and nuclear factor-kappa B (NF-kB) were investigated.

Results: Low and high doses of BWE showed significant prevention of abdominal fat accumulation ( $p<$ 0.05) and inhibited hypercholesterolemia without restoring triglyceride (TG) and lipoprotein-cholesterol $(L D L-C)$ in serum compared to rats fed HFD alone. BWE hindered hepatic fat accumulation via suppression of SREBP-1 expression and HMGCR activity in HFD-induced obese rats, while significantly promoting NF-kB down regulation $(p<0.05)$.

Conclusion: BWE may be a novel prophylactic strategy for preventing metabolic syndrome and to protect against steatosis due to its regulatory effects on lipid homeostasis.
\end{abstract}

Keywords: Benjakul, Fat metabolism, Non-alcoholic fatty liver disease, High-fat diet

\begin{abstract}
This is an Open Access article that uses a fund-ing model which does not charge readers or their institutions for access and distributed under the terms of the Creative Commons Attribution License (http://creativecommons.org/licenses/by/4.0) and the Budapest Open Access Initiative (http://www.budapestopenaccessinitiative.org/read), which permit unrestricted use, distribution, and reproduction in any medium, provided the original work is properly credited.
\end{abstract}

Tropical Journal of Pharmaceutical Research is indexed by Science Citation Index (SciSearch), Scopus, International Pharmaceutical Abstract, Chemical Abstracts, Embase, Index Copernicus, EBSCO, African Index Medicus, JournalSeek, Journal Citation Reports/Science Edition, Directory of Open Access Journals (DOAJ), African Journal Online, Bioline International, Open-J-Gate and Pharmacy Abstracts

\section{INTRODUCTION}

Being overweight or obese is strongly associated with and can cause metabolic syndrome. The risk factors due to obesity, especially visceral fat deposition and hypercholesterolemia, have a robust impact on the development of metabolic syndrome leading to pivotal causes of mortality
[1]. Being overweight is associated with high levels of plasma lipids and lead to metabolic disorders, such as increased plasma low-density lipoprotein-cholesterol (LDL-C) and triglyceride (TG) concentrations [2]. An imbalance in fatty acid metabolism results in the accumulation of TG in hepatocytes. Thus, non-alcoholic fatty liver disease (NAFLD) is the most common cause of 
liver disease. In general, dietary fat intake is a culprit of adiposity [3]. Increase in high fat mass potentiates associated risk conditions, such as dyslipidemia, type II diabetes mellitus, and coronary heart disease [4].

Moreover, high-fat diets (HFDs) contribute to glucose tolerance impairment and insensitivity of insulin toward blood glucose [5]. This impact is seen not only in humans but also in animals. Animals fed with a HFD for 4 weeks have a high propensity for obesity and abnormal lipid biomarkers [6].

In the concept of Ayurveda, dhatus (tissues) are the basic structures of the body [7]. The purpose of metabolism is to gather every dhatu together in harmony to achieve their individual roles within the body. According to animism, "Benjakul" is a mixture of elements that regulate body homeostasis [8]. In Thai traditional medicine pharmacopeia, Benjakul is associated with an ancient philosophical concept used to normalize the five primary elements.

The herbal components function as antioxidants, demonstrating broad pharmacological and biological benefits. The herbal elements not only have anti-cancer and cytotoxic activities, but some have an anti-diabetes effect. The major phytochemical constituent of Benjakul extract is piperine [9]. Significantly, piperine can reduce not only serum TG, total cholesterol (TC), and LDL-C levels, but also high-density lipoprotein (HDL) levels, affirming its beneficial effect on reducing dyslipidemia [10]. Unfortunately, most studies of Benjakul have focused only on toxicity.

In this study, we studied the effects of Benjakul supplementation on molecular modulation of rat liver abnormalities.

\section{EXPERIMENTAL}

\section{Preparation of Benjakul water extract (BWE)}

Benjakul is composed of five dried medicinal plants (Table 1). Five individual plants were collected from the Rayong Province, Thailand. The decoction method was based on the Thai Traditional Pharmacopeia guidelines.

All plants were cleaned and placed in a hot air oven at $55^{\circ} \mathrm{C}$ until dry. Dried plants were homogenized using a grinder. The powdered herbs were boiled at $100^{\circ} \mathrm{C}$ in water until half of the volume remained. The filtrate was evaporated via lyophilization.
Table 1: Composition of Benjakul water extract (BWE)

\begin{tabular}{llcc}
\hline $\begin{array}{l}\text { Common } \\
\text { name }\end{array}$ & Scientific name & $\begin{array}{c}\text { Part } \\
\text { used }\end{array}$ & $\begin{array}{c}\text { Content } \\
(\%)\end{array}$ \\
\hline $\begin{array}{l}\text { Wild betal } \\
\text { leaf bush }\end{array}$ & $\begin{array}{l}\text { Piper sarmentosum } \\
\text { Roxb. }\end{array}$ & Root & 44.4 \\
$\begin{array}{l}\text { Pepper } \\
\text { wood }\end{array}$ & $\begin{array}{l}\text { Piper interruptum } \\
\text { Opiz. }\end{array}$ & Stem & 22.2 \\
$\begin{array}{l}\text { Rose-color } \\
\text { lead wood }\end{array}$ & $\begin{array}{l}\text { Plumbago indica } \\
\text { Linn. }\end{array}$ & Root & 16.7 \\
$\begin{array}{l}\text { Long } \\
\text { pepper }\end{array}$ & $\begin{array}{l}\text { Piper retrofractum } \\
\text { Vahl. }\end{array}$ & Fruit & 11.1 \\
Ginger & $\begin{array}{l}\text { Zingiber } \\
\text { mekongense } \\
\text { Gagnep. }\end{array}$ & Rhizome & 5.6 \\
& & & \\
\hline
\end{tabular}

\section{Study design}

Forty 3-week-old male outbred Sprague-Dawley rats were obtained from the National Laboratory Animal Center, Nakhon Pathom, Thailand. All rats were maintained individually in stainless steel cages under standard conditions: 12-h lightdark cycle at $24^{\circ} \mathrm{C}$. Rats were fed a commercial standard chow diet for one week to acclimate. According to diet composition and treatments, rats were randomly divided into four groups: (1) standard chow (C), (2) HFD (HF), (3) HFD supplemented with low-dose BWE (HFB1, 41.3 $\mathrm{mg} / \mathrm{kg}$ body weight/day), and (4) HFD supplemented with high dose BWE (HFB10, 413 $\mathrm{mg} / \mathrm{kg}$ body weight/day). The energy of standard chow was $3.04 \mathrm{kcal} / \mathrm{g}$, whereas the HFD was $5.12 \mathrm{kcal} / \mathrm{g}$ (60\% fat). The obesity-inducing diet was modified from a study by Claret [11]. The HFD was composed of egg yolk (21.3\%), margarine $(21.3 \%)$, wheat flour $(15.9 \%)$, pork belly $(10.6 \%)$, pork liver (10.6\%), standard chow $(10.6 \%)$, sugar $(6.2 \%)$, and egg white $(3.5 \%)$.

Body weights and food intake were recorded daily during the experimental period. After 4 weeks, blood and tissue organs were collected for biochemical, pathological, and gene expression analyses. This protocol was permitted by the Animal Ethics Committee, Faculty of Medicine, Thammasat University (approval no. AE 001/2015) [12].

\section{Clinical biochemical analysis}

The TG, TC, and HDL-C concentrations in serum were measured using commercial enzymatic kits (Fluitest test kits, Analyticon Biotechnologies AG, Germany) using an enzymatic colorimetric method. LDL-C levels were calculated following the Friedewald equation [13]. 
Measurement of hepatic TC and TG accumulation

Hepatic TC and TG content were extracted from $50 \mathrm{mg}$ fresh liver using isopropanol following a previously established protocol [14]. Extracts were centrifuged at $10,000 \times \mathrm{g}$ for $15 \mathrm{~min}$ at $4^{\circ} \mathrm{C}$. TC and TG concentrations were measured using Fluitest lipid assay kits and expressed as $\mathrm{mg} / \mathrm{g}$ tissue.

\section{Determination of HMGCR activity}

Microsomal fraction was derived from one gram of liver tissue by homogenized and centrifuged at $100,000 \times \mathrm{g}$ for $60 \mathrm{~min}$ at $4^{\circ} \mathrm{C}$. HMGCR activities were measured using a commercial kit from Sigma-Aldrich, Saint Louis, MO, USA and expressed as $\mathrm{mmol} / \mathrm{min} / \mathrm{mg}$ protein (Units/mg protein).

\section{Histological examination}

For histologic examination, right ventral lobes of liver tissues and epididymal fat pads were fixed in $10 \%$ neutral-buffered formaldehyde, embedded in paraffin, cut using a rotary microtome, floated onto warm $\left(40-45^{\circ} \mathrm{C}\right)$ water to remove wrinkles, mounted on slides, and stained according to a standard hematoxylin and eosin (H\&E) protocol. Samples were examined for morphological observations under a light microscope (Olympus, Japan). The areas of adipocytes were measured using AxioVision AC (Carl Zeiss, Germany). Mean adipocyte areas were calculated from 100 cells observed/um².

\section{Quantitative reverse transcription- polymerase chain reaction (RT-PCR) analysis}

Total liver RNA was extracted by the TRIzol isolation method using the manufacturer's protocol (Invitrogen, Carlsbad, CA, USA). For quantitative RT-PCR, first-strand CDNA was synthesized from $200 \mathrm{ng}$ of total RNA using highcapacity cDNA reverse transcription kits (BioRad, Hercules, CA, USA) [15]. Samples were subjected to quantitative amplification using TaqMan probes and primer sets for rat SREBP1c (Rn1495769m1) and NF-kB p65 (Rn1502266m1). Relative mRNA levels were analyzed using the $2^{-\Delta \Delta C T}$ method. The expression of target genes was normalized to GAPDH (Rn99999916_s1) expression as a housekeeping gene.

\section{Western blot analysis}

Total proteins from liver tissues were isolated using cell lysis buffer (Cell Signaling Technology,
CAT\#9803, Danvers, MA, USA) following the manufacturer's instructions. Total protein concentrations were determined using Bradford protein assay kits (Bio-Rad, CAT\#5000201, Hercules, CA, USA). Extracted protein $(50 \mu \mathrm{g})$ was subjected to $7 \%$ sodium dodecyl sulfate polyacrylamide gel electrophoresis and transferred onto nitrocellulose membranes (BioRad). Membranes were blocked by a mixture of Odyssey blocking buffer (LI-COR Bioscience, Lincoln, NE, USA) for $1 \mathrm{~h}$ in the dark at room temperature and then, an overnight incubation in a primary anti-SREBP-1 antibody, anti-NF- $\mathrm{BB}$ p65 antibody, or anti-GAPDH antibody (Cell Signaling Technology, Danvers, MA, USA) at $4^{\circ} \mathrm{C}$. Membranes were washed with Tris-buffered saline containing $0.1 \%$ Tween-20. They were incubated with DyLight 680-conjugated antibodies (Cell Signaling Technology, Danvers, MA, USA) in the dark at room temperature for 1 h. The densities of each band were determined using an Odyssey Fc imaging system (LI-COR Bioscience, Lincoln, NE, USA) after washing. GAPDH protein levels were used for normalization.

\section{Statistical analysis}

All data are expressed as the mean \pm SEM, $n=8$ calculated using the IBM Statistics Package SPSS for Windows version 20. One-way ANOVA tests were used for statistical analysis of variance. Comparisons of the different groups were performed using least significant difference post-hoc tests. $P$ values $<.05$ were considered statistically significant for all data.

\section{RESULTS}

\section{Effect of BWE on body weight, organ weight, and histology of epididymal fat}

The $C$ group had a lower caloric intake compared to the HFD groups, even though the $C$ group consumed the highest amount of food. After 4 weeks of experimental diets, all HFD groups (HF, HFB1 and HFB10) showed increases in body weights by $24-39 \%$ compared with the control group (Table 2). The HFD groups showed a significant $(p<0.05)$ increase in both final body weight and internal organ weights. Importantly, the internal organ weights (epididymal and omental fat) of HFB10 rats were lower than that of the HF group (Figures $1 \mathrm{~A}, \mathrm{~B}$ and D). Histological H\&E staining confirmed increased epididymal adipocyte size in the HF group compared to the HFBL10 group (Figure 2). Quantitative assessment of adipocyte size indicated that the HF group had 2-fold larger 
epidermal adipocytes than did the HFBL1 and HFBL10 groups (Figure $1 \mathrm{C}$ ).
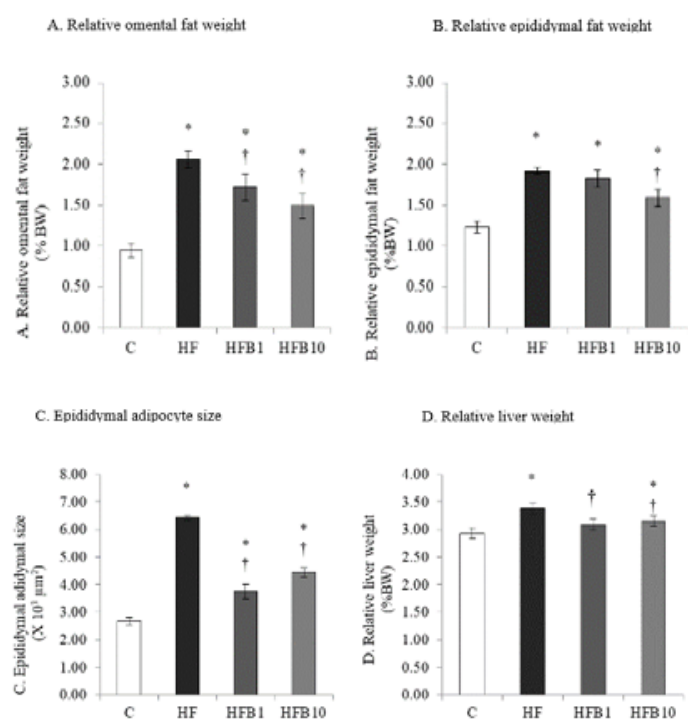

Figure 1: Effect of BWE on relative omental fat weight $(A)$, relative epididymal fat weight $(B)$, epididymal adipocyte size (C), and relative liver weight (D) in HFD-induced obese rats. Values are expressed as mean \pm SEM ( $n=8$ for tissue/organ weight, whereas $n$ $=3$ for adipocyte size). ${ }^{*} p<0.05$ vs. control, $\uparrow p<0.05$ vs. HF. C: control; HF: HFD alone; HFB1: HFD + BWE $41.3 \mathrm{mg} / \mathrm{kg}$; HFB10: HFD + BWE $413 \mathrm{mg} / \mathrm{kg}$

\section{Effect of BWE on hepatic TG accumulation}

HFDs not only induced obesity but also elevated circulating blood lipid levels. HFD-fed rats showed increased levels of TC (25.6\% increase) and TG (41.8\% increase) compared with the control animals. TC and LDL-C levels in the HFB1 group did not differ from the $C$ group. However, the lipid serum profile of the HFB10 group was attenuated. This was manifested in the reduced serum TG concentrations (18.9\% reduction) compared with the $\mathrm{C}$ group (Table 3 ). The HF group had a significant $(p<0.05)$ increase in the liver TG content. In comparison with the HF group, BWE supplementation prevented the robust increase in hepatic TG in the HFB1 and HFB10 groups (Figure 3). Moreover, BWE-fed rats had fewer visible signs of microvesicular or macrovesicular liver steatosis compared with HF rats (Figure 4). HMGCR activity increased significantly in the HF group compared with all treated groups (Figure $5)$.

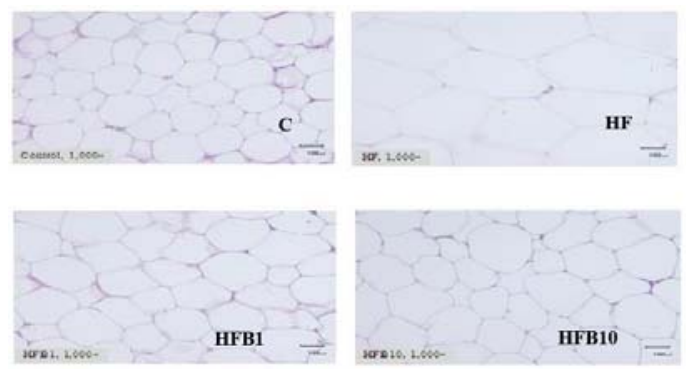

Figure 2: Histology of epididymal fat. H\&E staining, 1000x; scale bar $=100 \mu \mathrm{m}$. C: control; HF: HFD alone; HFB1: HFD + BWE $41.3 \mathrm{mg} / \mathrm{kg}$; HFB10: HFD + BWE $413 \mathrm{mg} / \mathrm{kg}$

Table 2: General characteristics of rat groups and their consumption

\begin{tabular}{|c|c|c|c|c|c|}
\hline $\begin{array}{l}\text { Treatment } \\
\text { group }\end{array}$ & $\begin{array}{l}\text { Daily amount of } \\
\text { diet }(g)\end{array}$ & $\begin{array}{c}\text { Daily energy } \\
\text { intake } \\
(\mathrm{kcal})\end{array}$ & $\begin{array}{l}\text { Initial body } \\
\text { weight }(g)\end{array}$ & $\begin{array}{l}\text { Final body } \\
\text { weight }(g)\end{array}$ & $\begin{array}{l}\text { Body weight } \\
\text { gain }(g)\end{array}$ \\
\hline C & $24.6 \pm 0.3$ & $74.8 \pm 1.0$ & $241.7 \pm 2.8$ & $367.4 \pm 4.6$ & $125.9 \pm 3.6$ \\
\hline $\mathrm{HF}$ & $22.3 \pm 0.3^{*}$ & $113.9 \pm 1.5^{*}$ & $241.3 \pm 3.5$ & $414.4 \pm 12.1^{*}$ & $173.4 \pm 9.0$ * \\
\hline HFB1 & $21.4 \pm 0.2^{*}$ & $110.0 \pm 1.3^{*}$ & $241.6 \pm 3.1$ & 414. $1 \pm 8.8^{*}$ & $172.6 \pm 7.5^{*}$ \\
\hline HFB10 & $19.8 \pm 0.6^{*}$ & $101.5 \pm 2.9^{*}$ & $243.1 \pm 3.4$ & $399.6 \pm 6.6^{*}$ & $156.5 \pm 7.9^{*}$ \\
\hline
\end{tabular}

Table 3: Effect of BWE on TC, LDL-C, HDL-C, and TG in serum

\begin{tabular}{lcccc}
\hline $\begin{array}{l}\text { Treatment } \\
\text { group }\end{array}$ & $\begin{array}{c}\text { Total Cholesterol } \\
(\mathrm{mg} / \mathrm{dL})\end{array}$ & $\begin{array}{c}\text { Low-density lipoprotein- } \\
\text { cholesterol } \\
(\mathrm{mg} / \mathrm{dL})\end{array}$ & $\begin{array}{c}\text { HDL-C } \\
\text { High-density } \\
\text { lipoprotein-cholesterol } \\
(\mathrm{mg} / \mathrm{dL})\end{array}$ & $\begin{array}{c}\text { TG } \\
\text { Triglycerides } \\
(\mathrm{mg} / \mathrm{dL})\end{array}$ \\
\hline C & $76.2 \pm 2.0$ & $32.2 \pm 5.3$ & $38.5 \pm 3.0$ & $28.7 \pm 1.6$ \\
HF & $95.7 \pm 2.8^{*}$ & $40.6 \pm 4.7$ & $37.8 \pm 3.5$ & $40.7 \pm 1.8^{*}$ \\
HFB1 & $79.4 \pm 3.0^{\dagger}$ & $24.3 \pm 1.7^{\dagger}$ & $46.9 \pm 2.0^{*}, \dagger$ & $36.7 \pm 2.5^{*}$ \\
HFB10 & $94.1 \pm 4.2^{*}$ & $41.8 \pm 2.9$ & $44.1 \pm 2.2$ & $33.0 \pm 2.5^{*}, \dagger$ \\
\hline Values are mean \pm SEM $(\mathrm{n}=8) ;{ }^{*} p<0.05 \mathrm{vs}$. control, $\dagger p<0.05 \mathrm{vs}$. HF. C: control; HF: HFD alone; HFB1: HFD + \\
BWE 41.3 mg/kg; HFB10: HFD + BWE 413 mg/kg
\end{tabular}




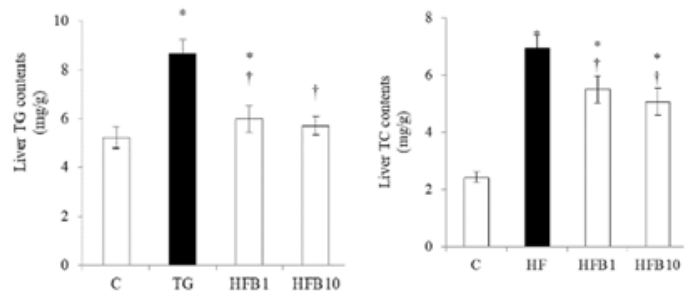

Figure 3: Hepatic lipid content. Values are mean \pm SEM $(\mathrm{n}=6)$; ${ }^{*} p<0.05$ vs. control, $\dagger p<0.05$ vs. HF. TC: total cholesterol; TG: total triglycerides; C: control; HF: HFD alone; HFB1: HFD + BWE $41.3 \mathrm{mg} / \mathrm{kg}$; HFB10: HFD + BWE $413 \mathrm{mg} / \mathrm{kg}$

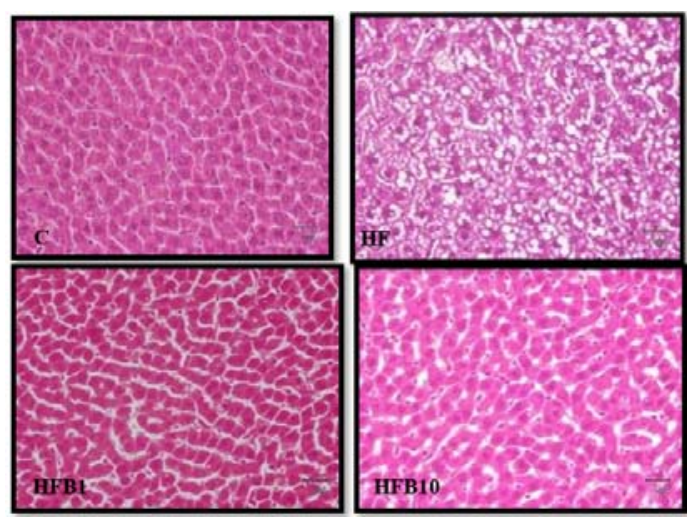

Figure 4: Histology of liver (H\&E staining, 400x; scale bar $=100 \mu \mathrm{m})$. C: control; HF: HFD alone; HFB1: HFD + BWE 41.3 mg/kg; HFB10: HFD + BWE 413 mg/kg

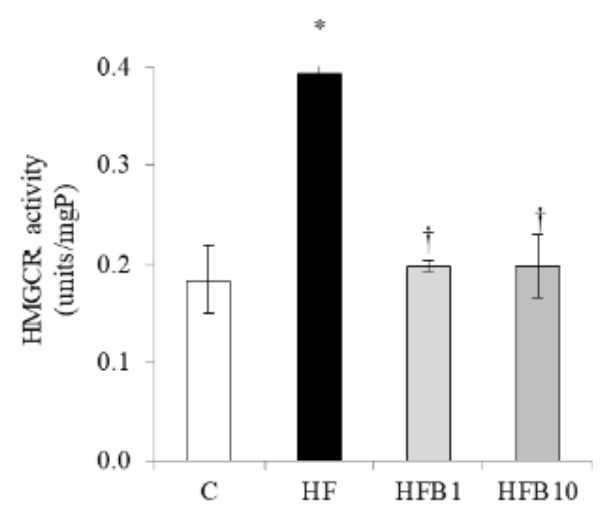

Figure 5: Effect of BWE on HMGCR activities. Values are mean $\pm \operatorname{SEM}(\mathrm{n}=3){ }^{*} p<0.05$ vs. control, $\dagger p<$ 0.05 vs. HF. C: control; HF: HFD alone; HFB1: HFD + BWE 41.3 mg/kg; HFB10: HFD + BWE 413 mg/kg

\section{Effect of BWE on gene expression}

SREBP1 mRNA (Figure 6A) and protein (Figure 6C) levels were significantly increased in the HF group compared with the $\mathrm{C}$ group, resulting in hepatic accumulation. However, the HFB10 group had SREBP1 mRNA and protein levels that were significantly lower than the HF group. Thus, BWE administration reduced inflammation by down-regulating liver NF- $\mathrm{B}$ mRNA levels, as observed in the HFB10 group.

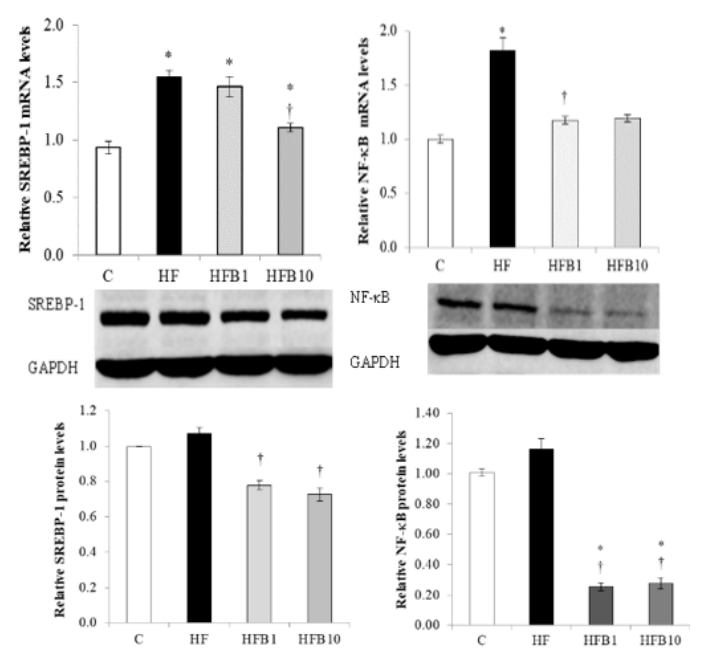

Figure 6: Effect of BWE on gene expression in HFDinduced obese rat livers. mRNA levels of SREBP-1 (A) and NF- $\kappa B$ p65 (B). Relative protein expression levels of SREBP-1 (C) and NF-kB (D). Values are mean \pm $\operatorname{SEM}(\mathrm{n}=6) ;{ }^{*} p<0.05$ vs. control, $\uparrow p<0.05$ vs. HF. C: control; HF: HFD alone; HFB1: HFD + BWE 41.3 $\mathrm{mg} / \mathrm{kg}$; HFB10: HFD + BWE 413 mg/kg

\section{DISCUSSION}

Obesity, dyslipidemia, hypertension, impaired glucose tolerance, and insulin resistance are a cluster of metabolic syndromes. Rats fed HFDs can develop these syndromes [16]. Benjakul is recognized in the Ayurvedic system of medicine for the control of body homeostasis [9]. Furthermore, a recent study suggested that piperine, an active ingredient in BWE, significantly lowers lipid and anti-obesity activity with no change in appetite [17]. In this study, TG levels were elevated in the HF group, indicating an increase in lipid metabolism and an energetic metabolic shift from glucose to lipids. Thus, treatment with BWE at low and high doses decreased the levels of TG in serum, resulting in attenuation of lipid metabolism. Moreover, the serum LDL-C levels were also significantly lower in HFB1 rats compared with those in the HF group.

Previous lipid metabolism studies demonstrated a correlation between lowering LDL-C and the reduction of metabolic syndrome, especially in cases of cardiovascular disease. HDL-C levels are also low in hyperlipidemia animal models [18]. However, substantial changes in HDL-C levels were not observed in the current study. Here, low doses of BWE were able to neutralize lipid metabolism. Excessive caloric intake from 
dietary fat causes TG storage in adipose tissue, resulting in an accumulation of visceral fat and may further cause adipocyte malfunction [19]. Importantly, reduced epididymal adipocyte size was observed in both groups that received BWE compared to the group fed a HFD alone ( $p<$ 0.05 ). Hence, improvement in metabolic rates generally correlates with a reduction in fat mass and size [20].

A hallmark of NAFLD is the accumulation of TG within hepatocytes. This arises from an imbalance between fatty acid synthesis and removal [3]. In this study, rats were fed HFDs, leading to the development of obesity, hypertriglyceridemia, and hypercholesterolemia. Rats fed HFDs and BWE showed fewer signs of microvesicular and macrovesicular liver steatosis when compared with rats fed only HFDs. These findings were associated with decreased HMGCR activity and SREBP-1 expression. De novo fatty acid synthesis was also regulated by the transcription factor SREBP1 that stimulates liver TG synthesis. The lipogenic enzymes involved these pathways, including fatty acid synthase (FAS) and acetyl-CoA carboxylase (ACC) [21]. The activity of HMGCR, a hepatic enzyme, correlates closely with cholesterolgenesis in target tissues and is the rate-limiting step in the synthesis of cholesterol. Defective regulation of HMGCR results in the accumulation of hepatic cholesterol in humans and rodents with metabolic syndrome [22].

Inflammation induced by hepatocyte stress responses may lead to lipid accumulation. Furthermore, dietary cholesterol is absorbed by the intestine, then entering to the hepatocyte. It is not only a lipid risk factor but also initiates the hepatic inflammation [23]. HFD-induced obesity in animal models is associated with hepatic steatosis and increased hepatic NF- $\kappa$ B activity [24]. Here, BWE supplementation decreased the relative mRNA and protein expression of hepatic $N F-\kappa B$. These data indicate that BWE supplementation obstructs $\mathrm{NF}-\kappa \mathrm{B}$ signaling, resulting in inhibition of liver inflammation.

No signs of gross toxicity were found after four weeks of BWE treatment. There are no harmful active ingredients found in BWE, even from Plumbagin, which may contain a toxic substance [25].

\section{CONCLUSION}

BWE treatment may prevent the initial development of metabolic syndrome.BWE treatment exhibited no significant differences in the overall risk factors for the development of metabolic syndrome. However, BWE can be considered an alternative nutritional supplement in preventive strategies to prevent or reduce fat deposition and obesity-associated complications.

\section{DECLARATIONS}

\section{Acknowledgement}

This work was supported by grants from the Research Unit, Faculty of Medicine, Thammasat University, Thailand.

\section{Conflict of interest}

No conflict of interest is associated with this work.

\section{Contribution of authors}

We declare that this work was done by the authors named in this article and all liabilities pertaining to claims relating to the content of this article will be borne by the authors.

\section{Open Access}

This is an Open Access article that uses a funding model which does not charge readers or their institutions for access and distributed under the terms of the Creative Commons Attribution License (http://creativecommons.org/licenses/by/ 4.0) and the Budapest Open Access Initiative (http://www.budapestopenaccessinitiative.org/rea d), which permit unrestricted use, distribution, and reproduction in any medium, provided the original work is properly credited.

\section{REFERENCES}

1. Zhang S, Zhou Z, Sun $Y$, Zhou P, Huang G, Peng J, Sun $S$, Zhang $Y$. High-dose pravastatin prevents autoimmune in non-obese diabetic mice. Diabetologia. 2007; 50(Supp/1): S189-S190.

2. Wang Z, Bao Z. Effect of anti-gut inflammatory agent on insulin resistance and lipid profile of mice fed different diets. Trop J Pharm Res 2017; 16 (11): 2651-2658.

3. Ipsen DH, Lykkesfeldt J, Tveden-Nyborg P. Molecular mechanisms of hepatic lipid accumulation in nonalcoholic fatty liver disease. Cell Mol Life Sci 2018; 75(18): 3313-3327.

4. Carr MC, Brunzell JD. Abdominal obesity and dyslipidemia in the metabolic syndrome: importance of type 2 diabetes and familial combined hyperlipidemia in coronary artery disease risk. J Clin Endocrinol Metab 2004; 89(1): 2601-2607.

5. Parklak $W$, Narongsuk Munkong $N$, Somnuk $S$, Somparn $N$, Jarinyaporn Naowaboot J, Yoysungnoen B, 
Lerdvuthisopon N. Rice bran water extract attenuates pancreatic abnormalities in high-fat diet-induced obese rats. Trop J Pharm Res 2017; 16 (4): 819-825.

6. Hariri $N$, Thibault L. High-fat diet-induced obesity in animal models. Nutr Res Rev 2010; 23(2): 270-299.

7. Mukhherjee $P K$, Harwansh RK, Bahadur $S$, Banerjee $S$, Kar A, Chabda J, Biswas S, Ahmmed SM, Katiyar CK. Development of Ayurveda - Tradition to trend. J Ethnopharmacol 2017; 2: 10-24.

8. Itharat A, Sakpakdeejaroen I. Determination of cytotoxic compounds of Thai traditional medicine called Benjakul using HPLC. J Med Assoc Thai 2010; 93(7): S198S203.

9. Rattarom R, Sakpakdeejaroen I, Hansakul P, Itharat A. Cytotoxic activity against small cell lung cancer cell line and chromatographic fingerprinting of six isolated compounds from the ethanolic extract of Benjakul. J Med Assoc Thai 2014; 97(8): S70-S75.

10. Kim KJ, Lee MS, Jo K, Hwang JK. Piperidine alkaloids from Piper retrofractum Vahl. protect against high-fat diet-induced obesity by regulating lipid metabolism and activating AMP-activated protein kinase. Biochem Biophys Res Commun 2011; 411(1): 219-225.

11. Claret M, Corominola H, Canals I, Nadal B, Chavanieu A, Pfeiffer B, Pierre Renard, Carmen Gorostiaga, Philippe Delagrange, Ge'rard Grassy, et al. S 23521 decreases food intake and body weight gain in diet-induced obese rats. Obes Res 2004; 12(10): 1596-1603.

12. National Research Council (US) Committee for the Update of the Guide for the Care and Use of Laboratory Animals. Guide for the Care and Use of Laboratory Animals. 8th edition. Washington (DC): National Academies Press (US); 2011 [cited 2013 Apr 3]. Available from: https://www.ncbi.nlm.nih.gov/books/NBK54050/

13. Fukuyama $N$, Homma $K$, Wakana $N, K u d o ~ K$, Suyama $A$, Ohazama $H$, Tsuji C, Ishiwata $K$, Eguchi $Y$, Nakazawa $H$, et al. Validation of the Friedewald Equation for Evaluation of Plasma LDL-Cholesterol. J Clin Biochem Nutr 2008; 43(1): 1-5.

14. Liu L, Gao C, Yao P, Ging Z. Quercetin alleviates high-fat diet-induced oxidized low-density lipoprotein accumulation in the liver: implication for autophagy regulation. Biomed Res Int 2015; 22: 1-9.

15. Hasdemir C, Aydin HH, Celik HA, Simsek E, Payzin S, Kayikcioglu M, Aydin M, Kultursay $H$, Can LH. T.
Transcriptional profiling of septal wall of the right ventricular outflow tract in patients with idiopathic ventricular arrhythmias. Pacing Clin Electrophysiol 2010; 33(2): 159-67.

16. Wong SK, Chin KY, Suhaimi FH, Fairus A, Nirwana SI. Animal models of metabolic syndrome: a review. Nutr Metab (Lond) 2016; 13: 1-12.

17. Shah SS, Shah GB, Singh SD, Gohil PV, Chauhan K, Shah KA, Chorawala $M$. Effect of piperine in the regulation of obesity-induced dyslipidemia in high-fat diet rats. Indian J Pharmacol 2011; 43(3): 296-299.

18. Katan MB, Grundy SM, Jones $P$, Law M, Miettinen $T$, Paoletti R. Efficacy and safety of plant stanols and sterols in the management of blood cholesterol levels. Mayo Clin Proc 2003; 78(8): 965-978.

19. Grundy SM. Adipose tissue and metabolic syndrome: too much, too little or neither. Eur J Clin Invest 2015; 45(11): 1209-1217.

20. Kumar AS, Maiya GA, Shastry BA, Vaishali K, Maiya Shubha, Umakanth $S$. Correlation between basal metabolic rate, visceral fat and insulin resistance among type 2 diabetes mellitus with peripheral neuropathy. Diabetes Metab Syndr 2019; 13: 344-348.

21. Xuguang Z, Shouqian C, Hailong L, Xiaopo Z, Feng C, Youbin $L$, Junnqing $Z$, Yinfeng $T$. Isolation and identification of two galangin metabolites from rat urine and determination of their in vitro hypolipidemic activity. Trop J Pharm Res 2016; 15(6): 1235-1241.

22. Wu N, Sarna $L K$, Hwang SY, Zhu $Q$, Wang $P$, Siow $Y L, O$ K. Activation of 3-hydroxy-3-methylglutaryl coenzyme $A$ (HMG-COA) reductase during high fat diet feeding. Biochim Biophys Acta 2013; 1832: 1560-1568.

23. Ma KL, Zhang Y, Liu J, Wu Y, Hu ZB, Liu L, Liu BC. Inflammatory stress induces lipid accumulation in multiorgans of db/db mice. Acta Biochim Biophys Sin 2015; 47(10): 767-774.

24. Somnuk S, Komindr S, Munkong N, Parklak W, Lerdvuthisopon N. Protective Effects of Rice Bran Water Extract (RBE) on Hepatic Fat Metabolism and Oxidative Damage in Rats Fed A High-Fat Diet. J Med Assoc Thai 2017; 100(6): 224.

25. Aziz MH, Dreckschmidt NE, Verma AK. Plumbagin, a medicinal plant-derived naphthoquinone, is a novel inhibitor of the growth and invasion of hormone refractory prostate cancer. Cancer Res 2008; 68(21): 9024-9032. 